\title{
Karakteristik Aliran pada Saluran Udara dengan Penambahan Square dan Circular Turbulator di Dekat Silinder Sirkular Tunggal
}

\author{
Randi Purnama Putra ${ }^{1^{*}}$, Bahrul Amin${ }^{1}$, Dori Yuvenda ${ }^{1}$ dan Nuzul Hidayat ${ }^{1}$ \\ ${ }^{1}$ Jurusan Teknik Otomotif, Fakultas Teknik, Universitas Negeri Padang \\ *Corresponding author, e-mail: randipurnama@ft.unp.ac.id
}

\begin{abstract}
Abstrak - Penggunaan silinder sirkular banyak ditemukan pada bentuk kontruksi aplikasi teknik seperti; heat exchanger, struktur penyangga anjungan lepas pantai, jembatan dermaga, sistem perpipaan dan sebagainya. Di dalam beberapa aplikasi teknik, silinder sirkular ditempatkan di dalam saluran dengan berbagai pengaturan. Penggunaan silinder sirkular di dalam saluran tentunya mengakibatkan perbedaan karakteristik aliran dan membuat bertambahnya pressure drop. Penelitian ini bertujuan melihat karakteristik aliran dengan penggunaan variasi turbulator didekat silinder sirkular. Karakteristik aliran yang di tinjau adalah pressure drop, distribusi tekanan pada silinder sirkular dan Koefisien drag pressure. Penelitian dilakukan secara eksperimen. Turbulator ditempatkan di depan dari silinder sirkular. Turbulator yang digunakan berbentuk square dan circular cylinder. Saluran udara memiliki penampang bujur sangkar dengan luas penampang 125 x $125 \mathrm{~mm}$. Rasio blockage sebesar 36,4\%. Variasi posisi sudut turbulator adalah dengan sudut $\alpha=20^{\circ}, 30^{\circ}, 40^{\circ}, 50^{\circ}$, dan $60^{\circ}$. Pengujian dilakukan pada Reynolds number 11,6 $\times 10^{4}$ (Re berdasarkan diameter hidrolik). Hasil dari penelitian menunjukkan penggunaan square turbulator lebih efektif mereduksi pressure drop pada saluran dibandingkan circular turbulator. Variasi posisi sudut square turbulator yang efektif mereduksi pressure drop ada pada sudut $\alpha=30^{\circ}$. Reduksi pressure drop pada sudut ini sebesar $23,33 \%$. Separasi aliran pada silinder sirkular terjadi pada sudut $110^{0}$ dan koefisien drag pressure sebesar 0,62 .
\end{abstract}

Kata kunci : Silinder Sirkular, Turbulator, Saluran Udara, Pressure Drop, Distribusi Tekanan

\begin{abstract}
The use of circular cylinder is found in many forms of engineering application construction such as; heat exchangers, offshore platform support structures, bridge piers, piping systems and so on. In some engineering applications, circular cylinder is placed in channels with various settings. The use of circular cylinder inside the channel certainly result in differences in flow characteristics and makes the pressure drop increase. This study aims to determine the flow characteristics with the use of turbulator variations near circular cylinder. Flow characteristics that are reviewed are pressure drop, pressure distribution on circular cylinders and drag coefficient pressure. The study was conducted experimentally. Turbulator is placed in front of a circular cylinder. Turbulator used is square and circular cylinder. The air duct has a square cross section with a cross section of $125 \times 125 \mathrm{~mm}$. Blockage ratio is 36,4\%. Variations in the angle position of the turbulator are at angles $20,30,40,50$, and 60 degree. The test is carried out at Reynolds number $11,6 \times 10^{4}$ (Re based on hydraulic diameter). The results of the study show that the use of square turbulator is more effective at reducing pressure drop on the channel than circular turbulator. Variations in the position of the square turbulator angle that effectively reduce the pressure drop is at an angle of 30 degree. The reduction in pressure drop at this angle is 23,33 $\%$. Flow separation on the circular cylinder occurs at an angle of 110 degree and drag coefficient pressure is 0,62 .
\end{abstract}

Keywords : Circular Cylinder, Turbulator, Ducting, Pressure Drop, Pressure Distribution

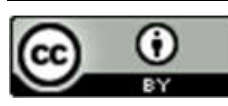

This is an open access article distributed under the Creative Commons 4.0 Attribution License

\section{Pendahuluan}

Silinder sirkular adalah salah satu bentuk bluff body yang paling banyak digunakan pada aplikasi engineering. Aplikasi dari silinder sirkular biasanya digunakan pada cerobong asap, tiang, alat penukar kalor shell and tube atau tube banks, jembatan dermaga, periskop, bejana bertekanan atau reaction tower pada pabrik kimia, cooling 
tower, pendingin komponen elektronik (electronic cooling), dan sebagainya.

Adanya silinder sirkular mengakibatkan timbulnya normal stress dan shear stress. Normal stress timbul karena adanya tekanan dari fluida yang melintasi bluff body, sedangkan shear stress timbul karena adanya pengaruh viskositas dari fluida yang melintasi bluff body. Interaksi antara aliran fluida dan silinder sirkular ini juga akan menimbulkan pressure drop didalam saluran.

Penelitian ini bertujuan untuk mengetahui karakteristik aliran didalam saluran udara. Karakteristik aliran yang ditinjau adalah pressure drop, distribusi tekanan dan koefisien drag pressure. Didalam saluran udara terpasang konfigurasi silinder sirkular dengan turbulator berbentuk square dan circular cylinder.

\section{StUdi PUSTAKa}

Banyak penelitian dilakukan untuk mengetahui karakteristik aliran fluida terutama dalam pembakaran [1] [2]. Hal tersebut dilakukan untuk kepentingan akademik maupun untuk kepentingan industri. Dalam beberapa aplikasi teknik, banyak penelitian yang dilakukan untuk mengetahui karakteristik aliran yang melintasi suatu bluff body. Salah satu bluff body yang banyak digunakan adalah silinder sirkular. Bentuk dari silinder, konfigurasi dan variasi diameter akan menimbulkan fenomena aliran yang berbeda. Fenomena aliran ini bisa berupa gaya hambat atau drag.

Silinder sirkular yang dilalui aliran fluida di sekelilingnya akan terbentuk suatu boundary layer [3]. Jika momentum aliran tidak mampu mengatasi gaya-gaya fluida yang timbul dan adverse pressure gradient (APG) membesar, maka boundary layer akan mengalami pemisahan dari kontur body. Pemisahan dari dari kontur body ini dinamakan separasi aliran. Separasi aliran yang terjadi pada silinder sirkular akan menyebabkan terbentuknya suatu daerah yang disebut sebagai wake. Jika titik terbentuknya separasi aliran semakin kedepan, maka wake akan menjadi lebih lebar sehingga gaya-gaya fluida yang terjadi juga semakin besar.

Penelitian mengenai aliran fluida melewati silinder sirkular tunggal dilakukan oleh [4]. Penelitian ini lebih banyak mengolah data sekunder yang didapat dari penelitian-penelitian sebelumnya dengan membahas interaksi antara aliran fluida dengan silinder sirkular. Didapat sebuah kesimpulan bahwa aliran fluida akan bertransisi dari aliran laminar menjadi turbulen hingga terjadi fenomena separasi aliran. Fenomena ini sangat dipengaruhi oleh beberapa faktor yaitu oleh kecepatan pada free-stream serta profil alirannya, free-stream turbulence (intensitas turbulensi), bentuk benda (geometri maupun orientasi terhadap arah alirannya), serta kekasaran permukaan benda.

Penggunaan silinder sirkular didalam saluran mengakibatkan efek pressure drop tidak dapat diabaikan. Hal ini diakibatkan gaya hambat yang dihasilkan dari penggunaan silinder sirkular didalam saluran. Semakin besar diameter silinder sirkular maka akan menyebabkan gaya $\operatorname{drag}\left(C_{D}\right)$ semakin meningkat [5] [6]. Selain itu, penggunaan silinder sirkular didalam saluran mengakibatkan efek blockage tidak dapat diabaikan. Ini disebabkan semakin sempitnya daerah yang dapat dilalui oleh fluida. Nilai $C_{D}$ yang semakin besar mengindikasikan nilai intensitas turbulensi yang semakin kecil [7]. Pada sebagian besar aplikasi teknik, terutama struktur bangunan dimana silinder sirkular ini biasa digunakan, adanya gaya hambat atau drag tidak diinginkan.

Gaya drag ini sangat dipengaruhi oleh posisi titik separasi aliran fluida pada silinder sirkular. Secara umum parameter yang biasa dilakukan untuk reduksi gaya hambat atau $d r a g$ adalah variasi geometri silinder, pengganggu aliran maupun variasi jarak. Penelitian dalam hal reduksi pressure drop di dalam saluran berbentuk bujur sangkar sudah banyak dilakukan. Terutama penelitian berupa pengaruh jarak $(s / D)$ peletakan silinder sirkular dan variasi Reynolds number terhadap nilai pressure drop pada saluran. Hasil penelitian menunjukkan besarnya nilai pressure drop sangat dipengaruhi oleh besarnya nilai Reynolds number. Semakin besar nilai Reynolds number maka akan semakin besar juga nilai pressure drop yang didapatkan [8]. Selain itu, reduksi pressure drop paling minimum ada pada peletakan silinder sirkular dengan jarak $s / D=1-1,4$ di dalam saluran.

Berbagai cara dilakukan untuk mereduksi pressure drop didalam saluran. Pada umumnya, teknik pengontrolan aliran fluida pada silinder sirkular diklasifikasikan dalam dua jenis, yaitu metode pengontrolan pasif dan aktif. Metode pengontrolan aktif yaitu mengontrol aliran fluida dengan cara mensuplai energi dari luar seperti penambahan hembusan jet, sedangkan metode pengontrolan pasif mengontrol aliran fluida dengan cara memodifikasi bentuk silinder sirkular dengan cara menempatkan alat tambahan seperti batang pengontrol atau dengan menempelkan elemen tambahan pada silinder sirkular untuk menambah kekasaran permukaan. Metode pengontrolan aktif memerlukan peralatan yang kompleks untuk mensuplai energi dari luar kepada aliran. Oleh 
karena itu, metode pengontrolan pasif lebih mudah untuk diaplikasikan.

Salah satu cara dalam mereduksi pressure drop adalah dengan penambahan turbulator didekat silinder sirkular. Penambahan turbulator ini termasuk dalam metode pengontrolan pasif. Penggunaan turbulator dapat mereduksi gaya drag yang terjadi pada silinder sirkular dengan menggunakan saluran lebar blokage ratio $4 \%$ [9]. Dengan adanya turbulator di depan silinder sirkular maka akan membuat aliran fluida lebih turbulen sehingga diharapkan dapat melawan adverse pressure gradient yang terjadi, karena pada aliran yang turbulen memiliki momentum kecepatan yang cukup besar, sehingga akan menunda titik separasi dan daerah wake yang terbentuk pun akan menjadi lebih sempit [10] [11].

Penggunaan batang pengontrol atau turbulator tidak hanya berbentuk circular cylinder saja, tetapi bisa bentuk lainnya. Penelitian dengan variasi benda uji berupa circular cylinder, square cylinder dan oriented square cylinder dengan panjang sisi $20 \mathrm{~mm}$ dilakukan oleh [12]. Penelitiannya dengan menggunakan metode digital particle image velocimetry $(D P I V)$ dan dilakukan pada close loop free surface water channel. Dari penelitiannya didapatkan kesimpulan bahwa penggunaan square cylinder ataupun oriented square cylinder menghasilkan nilai intensitas turbulensi yang lebih besar daripada penggunaan circular cylinder, hal ini dapat dilihat dari nilai kandungan energi turbulennya.

\section{Metode}

Penelitian dilakukan secara eksperimen. Skema penelitian berupa konfigurasi silinder sirkular tunggal dengan penambahan square dan circular turbulator. Silinder sirkular memiliki diameter $37,5 \mathrm{~mm}\left(d / D_{h}=0,3\right)$. Turbulator mempunyai panjang sisi $4 \mathrm{~mm}\left(s / D_{h}=0,032\right)$. Variasi posisi sudut untuk turbulator pada penelitian ini adalah sudut $\alpha=20^{\circ}, 30^{\circ}, 40^{\circ}, 50^{\circ}$ dan $60^{\circ}$. Sedangkan gap antara turbulator dengan silinder sirkular dibuat konstan pada jarak 0,4 $\mathrm{mm}$. Skema dari penelitian yang akan dilakukan dapat dilihat pada gambar 1 .

Peralatan yang digunakan dalam eksperimen ini meliputi wind tunnel, tes section, inverter, tranducer, data akuisisi (DAQ) dan pitot tube. Untuk pengujian dilakukan dalam skala model. Pengujian dilakukan dengan menggunakan wind tunnel yang pembuatan kondisi-kondisinya mendekati kenyataan, sehingga hasilnya pun cukup akurat dan memadai. Wind tunnel yang digunakan dalam percobaan ini adalah wind tunnel jenis open circuit wind tunnel. Dimana udara yang dialirkan dalam wind tunnel langsung dilepas bebas ke udara bebas setelah melalui work section. Untuk mendapatkan hasil penelitian yang akurat diperlukan alat ukur. Pada eksperimen ini untuk mendapatkan tekanan statis dan tekanan stagnasi digunakan wall-pressure tap, pitot static tube dan pressure tranducer. Untuk performance dari pressure tranducer dapat dilihat pada tabel 1.

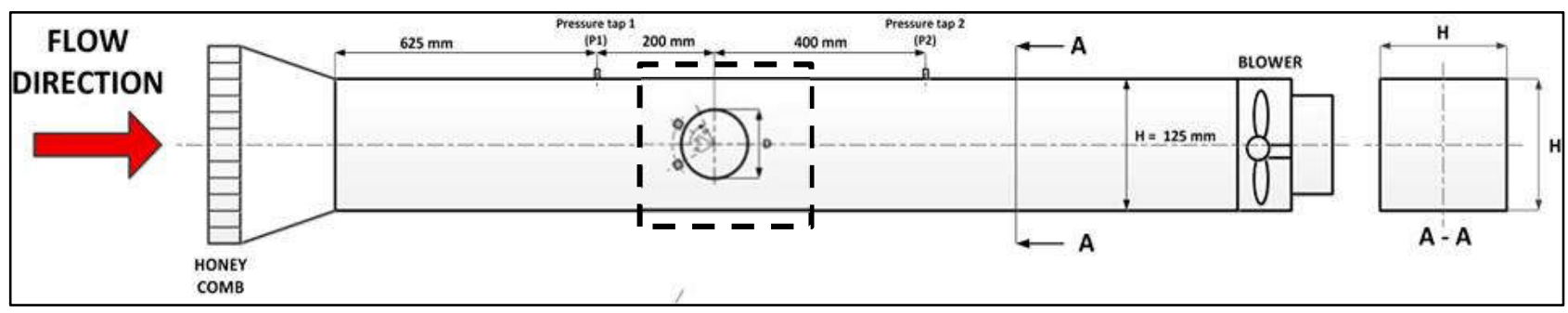

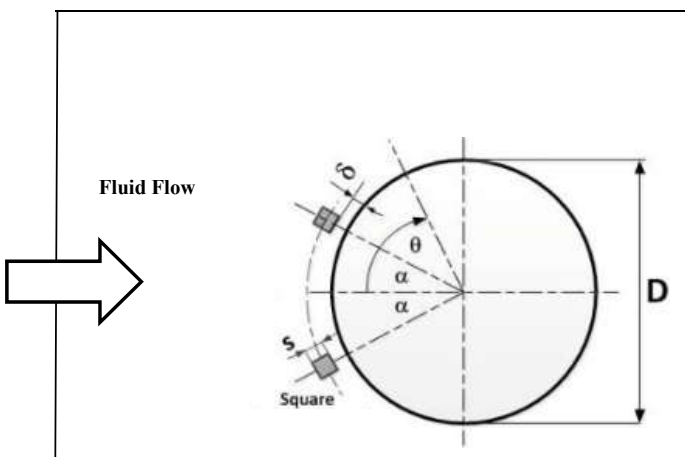

(a)

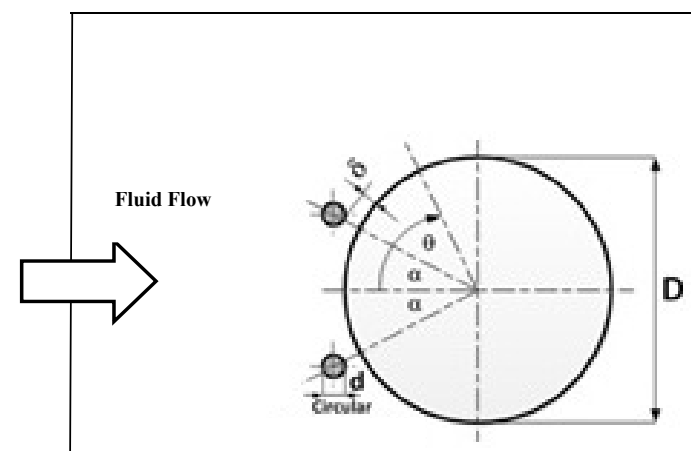

(b)

Gambar 1. Detail Eksperimen a) silinder sirkular dengan square turbulator (ST) b) Silinder sirkular dengan circular turbulator (CT) 
Tabel 1. Performance dari pressure tranducer

\begin{tabular}{ll}
\hline Specifications & PX-653 \\
Excitation & 12 to $36 \mathrm{Vdc}$ \\
Output & 1 to $5 \mathrm{Vdc}(2$ wire $)$ \\
Linearity & $0.3 \% \mathrm{FS}(\mathrm{BFSL})$ \\
Hysteresis & $0.02 \% \mathrm{FS}$ \\
Repeatability & $0.05 \% \mathrm{FS}$ \\
Operating Temperature & -29 to $72^{\circ} \mathrm{C}\left(-20\right.$ to $160{ }^{\circ} \mathrm{F}$, \\
Pressure Range & $0-1$ ' $\mathrm{WC}(248,18 \mathrm{~Pa})$ \\
\hline
\end{tabular}

Karakteristik aliran didalam saluran yang ditinjau adalah pressure drop, distribusi tekanan $(C p)$ dan koefisien drag pressure $\left(C_{d p}\right)$. Pengukuran pressure drop digunakan untuk mengetahui kehilangan tekanan akibat gesekan pada saluran. Pengambilan data pressure drop dilakukan pada Reynolds Number 11,6 x 104, dengan Reynolds Number berdasarkan diameter hidrolik saluran. Untuk pembacaan data pressure drop digunakan pressure tap pada wall wind tunnel. Sedangkan pembacaan data distribusi tekanan dan drag coeffisien pressure digunakan wall-pressure tap pada kontur silinder, yang dihubungkan dengan pressure tranducer dan data akuisisi.

\section{HASIl DAN PEMBaHASAN}

Pada bagian ini ditampilkan data hasil eksprimen berupa grafik beserta penjelasannya. Data terdiri dari grafik pressure drop $(\Delta P)$, koefisien tekanan $(C p)$ dan koefisien drag pressure $\left(C_{d p}\right)$ dari setiap konfigurasi benda uji yang dilakukan. Adapun grafik yang ditampilkan adalah konfigurasi saluran dengan silinder sirkular dan saluran dengan silinder sirkular tunggal ditambah square dan circular turbulator disisi upstream silinder sirkular.

\section{A. Pressure Drop}

Pressure drop didapatkan dari data perbedaan tekanan dari pressure tap inlet dan pressure tap outlet yang terdapat pada test section. Gambar 2 merupakan grafik nilai pressure drop yang dihasilkan oleh saluran dengan konfigurasi silinder sirkular tunggal $d / D_{h}=0,3$ dan saluran dengan penggunaan silinder sirkular tunggal dengan penambahan square dan circular turbulator. Hitung nilai $\Delta P$ menggunakan persamaan 1:

$$
\frac{\Delta P}{\rho}=h_{l t}=h_{\text {lmayor }}+h_{\text {lminor }}
$$

Pada gambar 2 secara umum terlihat bahwa nilai pressure drop yang dihasilkan oleh konfigurasi silinder sirkular tunggal ditambah square dan circular turbulator dengan sudut $\alpha=30^{\circ}$ mempunyai nilai pressure drop terendah dibandingkan saluran dengan silinder sirkular. Pada sudut ini terlihat bahwa nilai pressure drop yang dihasilkan oleh konfigurasi silinder sirkular tunggal dan square turbulator mempunyai nilai pressure drop terendah, diikuti oleh konfigurasi silinder sirkular tunggal dengan circular turbulator. Pada square turbulator memiliki nilai pressure drop sebesar 70,26 $\mathrm{Pa}$ dan circular turbulator sebesar 72,45. Informasi lain didapatkan bahwa penggunaan konfigurasi silinder sirkular dengan square dan circular turbulator juga efektif mengurangi nilai pressure drop pada sudut $\alpha=20^{\circ}$ dan $40^{\circ}$. Sedangkan pada sudut $\alpha=50^{\circ}$ dan $60^{\circ}$ mempunyai nilai pressure drop yang jauh lebih besar daripada silinder sirkular tunggal, sehingga penggunaan konfigurasi ini tidak efektif lagi mereduksi nilai pressure drop.

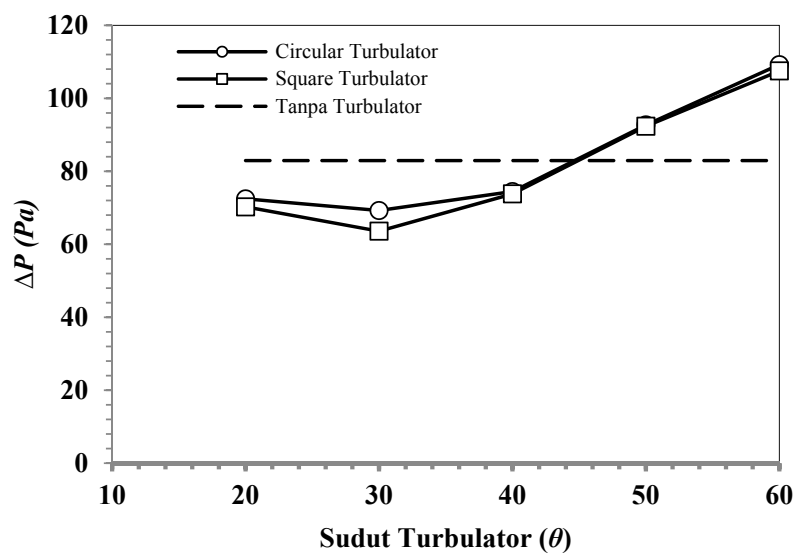

Gambar 2. Pressure Drop

Hal ini diakibatkan karena penggunaan square dan circular turbulator membuat headloss minor yang terjadi semakin kecil. Dengan adanya turbulator maka terjadi interaksi antara wake yang terlepas dari turbulator dengan boundary layer pada silinder sirkular tunggal. Hal ini akan mempercepat transisi boundary layer pada silinder sirkular dari laminar ke turbulen. Aliran fluida yang lebih turbulen mengindikasikan momentum aliran yang terjadi lebih besar. Momentum aliran yang lebih besar membuat aliran mampu melawan adverse pressure gradient ( $A P G$ ) yang terjadi pada silinder sirkular tunggal. Akibatnya wake yang dihasilkan lebih sempit. Wake yang lebih sempit mengindikasikan gaya hambat yang lebih kecil. Dengan berkurangnya gaya hambat tersebut mengakibatkan headloss minor yang ditimbulkan juga akan semakin kecil, Maka nilai pressure drop yang terjadi akan semakin kecil.

Pada tabel 2 terlihat bahwa penggunaan dari square turbulator pada sudut $\alpha=30^{0}$ dapat mereduksi pressure drop sebesar 23,33 \%. 
Sedangkan pada tabel 3 menunjukkan penggunaan circular turbulator pada $\alpha=30^{\circ}$ hanya dapat mereduksi pressure drop sebesar 16,51\%. Hal ini menunjukkan bahwa momentum aliran yang dihasilkan akibat penggunaan dari square turbulator lebih besar dibandingkan penggunaan circular turbulator.

Tabel 2. Pressure drop pada saluran dengan penambahan square turbulator $(S T)$

\begin{tabular}{|c|c|c|}
\hline Variasi & $\Delta P\left(N / m^{2}\right)$ & $\Delta P(\%)$ \\
\hline saluran + silinder sirkular & 82,95 & - \\
\hline $\begin{array}{c}\text { saluran }+ \text { silinder sirkular }+ \\
S T \text { sudut } 20^{\circ}\end{array}$ & 70,26 & $-15,30$ \\
\hline $\begin{array}{c}\text { saluran }+ \text { silinder sirkular }+ \\
\text { ST sudut } 30^{\circ}\end{array}$ & 63,59 & $-23,33$ \\
\hline $\begin{array}{c}\text { saluran }+ \text { silinder sirkular }+ \\
S T \text { sudut } 40^{\circ}\end{array}$ & 73,82 & $-11,01$ \\
\hline $\begin{array}{c}\text { saluran }+ \text { silinder sirkular }+ \\
S T \text { sudut } 50^{\circ}\end{array}$ & 92,35 & 11,34 \\
\hline $\begin{array}{c}\text { saluran }+ \text { silinder sirkular }+ \\
S T \text { sudut } 60^{\circ}\end{array}$ & 107,50 & 29,61 \\
\hline
\end{tabular}

Tabel 3. Pressure drop pada saluran dengan penambahan circular turbulator $(C T)$

\begin{tabular}{|c|c|c|}
\hline Variasi & $\Delta P\left(N / m^{2}\right)$ & $\Delta P(\%)$ \\
\hline saluran + silinder sirkular & 82,95 & - \\
\hline $\begin{array}{c}\text { saluran }+ \text { silinder sirkular }+ \\
C T \text { sudut } 20^{\circ}\end{array}$ & 72,45 & $-12,66$ \\
\hline $\begin{array}{c}\text { saluran }+ \text { silinder sirkular }+ \\
C T \text { sudut } 30^{\circ}\end{array}$ & 69,25 & $-16,51$ \\
\hline $\begin{array}{c}\text { saluran }+ \text { silinder sirkular }+ \\
C T \text { sudut } 40^{\circ}\end{array}$ & 74,46 & $-10,24$ \\
\hline $\begin{array}{c}\text { saluran }+ \text { silinder sirkular }+ \\
C T \text { sudut } 50^{\circ}\end{array}$ & 92,71 & 11,78 \\
\hline $\begin{array}{c}\text { saluran }+ \text { silinder sirkular }+ \\
C T \text { sudut } 60^{\circ}\end{array}$ & 109,24 & 31,70 \\
\hline
\end{tabular}

\section{B. Distribusi Tekanan (Cp)}

Distribusi tekanan merupakan selisih antara tekanan statis pada kontur permukaan dengan tekanan statis freestream kemudian dibagi dengan tekanan dinamis, Nilai dari distribusi tekanan yang dibahas pada bagian ini adalah distribusi tekanan pada silinder tunggal dan distribusi tekanan pada silinder sirkular tunggal dengan penambahan square dan circular turbulator. Nilai distribusi koefisien tekanan diperoleh dari pembacaan dua pressure tap yang diletakkan pada sudut kontur $0^{\circ}$ dan $180^{\circ}$ dengan pengambilan data setiap interval $5^{\circ}$. Dalam analisa distribusi tekanan digunakan persamaan 2:

$$
C_{p}=\frac{p_{c}-p_{\infty}}{1 / 2 \cdot \rho \cdot U^{2}}
$$

dimana :

$$
p_{\mathrm{c}} \quad=\text { Tekanan statis pada kontur lokal }
$$

$$
\begin{aligned}
& p_{\infty} \quad=\text { Tekanan statis aliran bebas } \\
& 1 / 2 \cdot \rho \cdot U^{2}=\text { Tekanan dinamis aliran bebas }
\end{aligned}
$$

Pada gambar 3 terlihat distribusi tekanan yang terjadi sepanjang aliran melintasi silinder sirkular tunggal serta silinder sirkular dengan penambahan square dan circular turbulator. Dari gambar bisa dilihat bahwa titik stagnasi terjadi pada sudut $0^{\circ}$ dengan menghasilkan $C p$ dengan nilai 1. Pada silinder sirkular tunggal, aliran fluida dari titik stagnasi mengalami percepatan hingga kecepatan maksimal, ditandai dengan menurunnya $C p$ hingga tekanan minimum $-1,79$ pada sudut $70^{\circ}$. Terjadinya percepatan aliran ini disebabkan karena penyempitan stream tube dari titik stagnasi hingga pada titik dengan tekanan minimum, dalam artian aliran melalui daerah favourable. Setelah sudut $70^{\circ}$ aliran fluida mengalami perlambatan akibat friction, ini ditandai dengan nilai distribusi koefisien tekanan meningkat dan mencapai nilai tertingginya pada sudut $90^{\circ}$. Pada sudut $90^{\circ}$ ini, aliran mengalami separasi. Titik separasi silinder sirkular tunggal ditandai dengan mulai mendatarnya distribusi koefisien tekanan.

Separasi diakibatkan oleh momentum aliran yang tidak mampu melawan adverse pressure sehingga aliran mengalami pemisahan dari kontur bodi silinder sirkular. Dibelakang titik separasi, terdapat shear layer serta terbentuk wake. Pada eksperimen ini didapatkan nilai koefisien tekanan base $\left(C_{P B}\right)$ sebesar -1.5 untuk silinder sirkular tunggal.

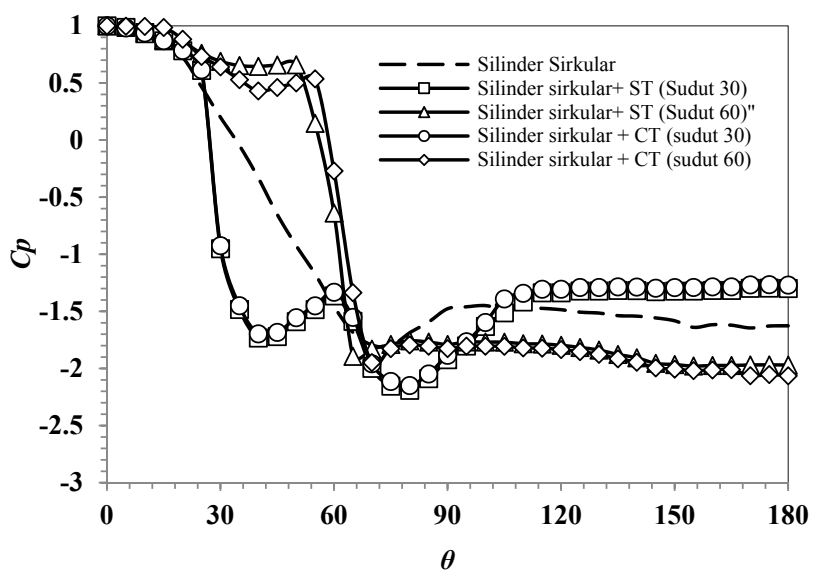

Gambar 3. Distribusi Tekanan

Berbeda halnya dengan distribusi tekanan pada silinder sirkular tunggal. Pada silinder sirkular dengan penambahan square dan circular turbulator sudut $30^{\circ}$, terlihat adanya fenomena reattachment, penundaan titik separasi serta nilai koefisien tekanan base $\left(\mathrm{C}_{\mathrm{PB}}\right)$ yang lebih besar dari 
silinder sirkular tunggal. Distribusi koefisien tekanan mengalami penurunan pada silinder sirkular tunggal dengan penambahan turbulator hingga sudut $40^{\circ}$. Turunnya nilai distribusi kecepatan ini menandakan adanya sebuah percepatan aliran fluida. Setelah sudut $40^{\circ}$ aliran fluida mengalami perlambatan akibat friction, ini ditandai oleh nilai distribusi koefisien tekanan meningkat dan mencapai nilai tertingginya pada sudut $60^{\circ}$. Pada sudut ini, aliran mengalami separasi. Setelah mengalami separasi, aliran kemudian menempel kembali pada kontur body silinder sirkular (reattachment) sehingga terjadi mixing antara shear layer yang terlepas dari turbulator dengan boundary layer silinder sirkular tunggal. Kemudian aliran tersebut mengalami percepatan hingga sudut $80^{\circ}$ akibat momentum aliran yang besar. Setelah sudut $80^{\circ}$ ini, aliran mengalami deselerasi atau perlambatan akibat friction, hingga akhirnya mengalami separasi aliran pada sudut $110^{\circ}$ untuk silinder sirkular dengan penambahan square turbulator. Sedangkan titik separasi pada silinder sirkular dengan penambahan circular turbulator terjadi pada sudut $105^{\circ}$. Untuk melihat pola aliran pada silinder sirkular dengan penambahan turbulator, dapat dilihat topologi aliran pada gambar 4 .
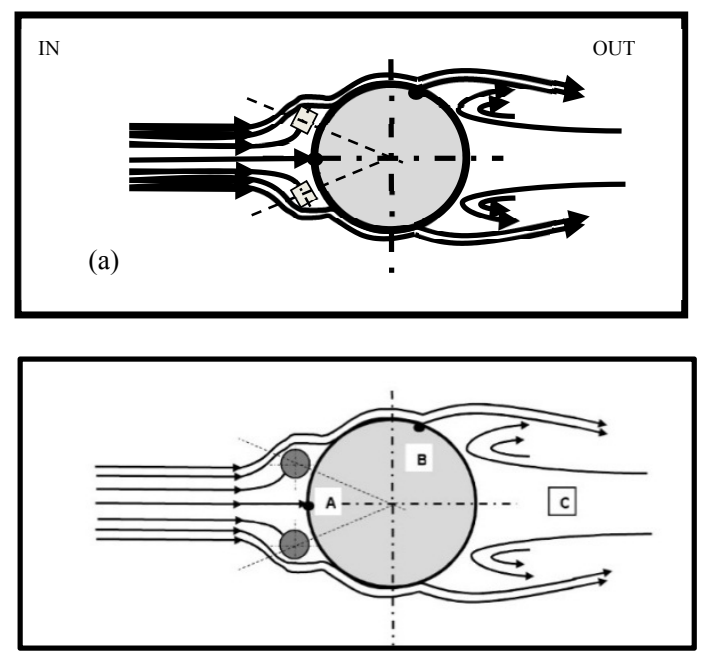

Gambar 4. Topologi aliran dengan turbulator pada sudut $30^{\circ}$ a) square turbulator, b) circular turbulator

Sedangkan distribusi tekanan pada silinder sirkular dengan penambahan square dan circular turbulator menunjukkan separasi aliran terjadi pada sudut $75^{\circ}$ (gambar 3). Adapun nilai koefisien tekanan base bernilai -1,90. Ini menunjukkan penggunaan dari square dan circular turbulator tidak efektif lagi pada sudut $60^{\circ}$. Untuk melihat pola aliran pada silinder sirkular tunggal dengan penambahan square dan circular turbulator sudut $60^{\circ}$, dapat dilihat topologi aliran pada gambar 5 .
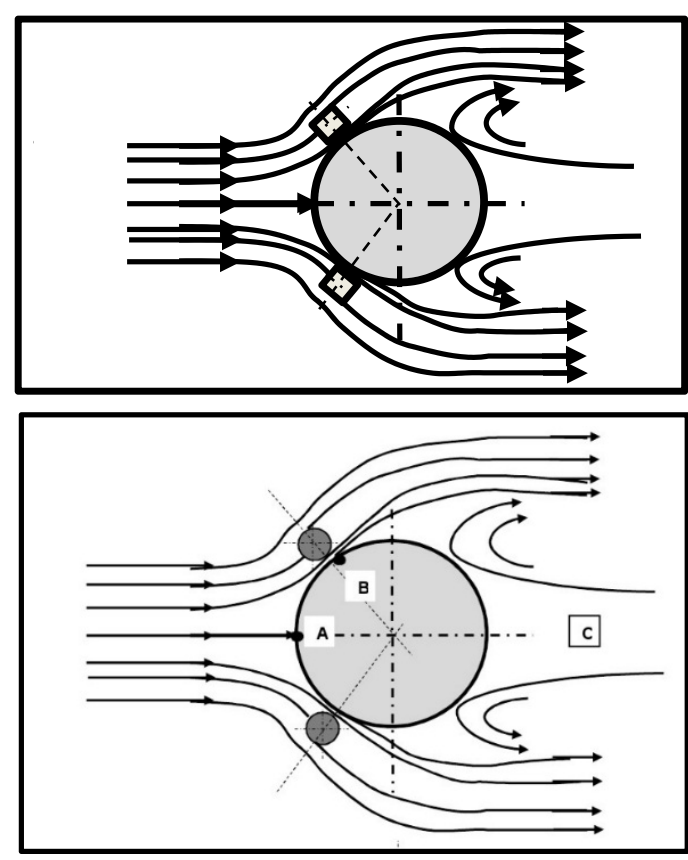

Gambar 5. Topologi aliran dengan turbulator pada sudut $60^{\circ}$ a) square turbulator, b) circular turbulator

\section{Koefisien Drag Pressure}

Koefisien drag pressure merupakan bilangan tak berdimensi yang terdapat pada gaya drag. Koefisien drag pressure dalam eksperimen ini didapatkan dari integrasi numerik distribusi koefisien tekanan pada silinder sirkular. Kemudian dengan menggunakan rumus maka didapatkan perhitungan koefisien drag pressure $\left(C_{D p}\right)$. Rumus yang digunakan adalah persamaan 3 :

$$
\mathrm{C}_{\mathrm{Dp}}=\frac{1}{2} \int_{0}^{2 \pi} \mathrm{C} \mathrm{p}(\theta) \cos (\theta) \mathrm{d} \theta .
$$

Nilai koefisien drag pressure berkaitan erat dengan nilai distribusi koefisien tekanan $(C p)$. Pada gambar 6 merupakan grafik nilai koefisien drag pressure $\left(C_{D p}\right)$ pada silinder sirkular tunggal serta silinder sirkular dengan penambahan square dan circular turbulator. Nilai koefisien drag pressure $\left(C_{D p}\right)$ dari penggunaan turbulator lebih kecil pada sudut $\alpha=20^{\circ}, 30^{\circ}$ dan $40^{\circ}$, dibandingkan dengan nilai koefisien drag pressure $\left(C_{D p}\right)$ dari silinder sirkular tunggal. Sedangkan pada turbulator dengan sudut $\alpha=50^{\circ}$ dan $60^{\circ}$, nilai $C_{D p}$ yang dihasilkan lebih besar daripada nilai $C_{D p}$ silinder sirkular tunggal. Hal ini disebabkan dengan bertambahnya besarnya sudut dari turbulator, maka blockage ratio yang dihasilkan semakin besar, sehingga nilai $C_{D p}$ semakin besar. 


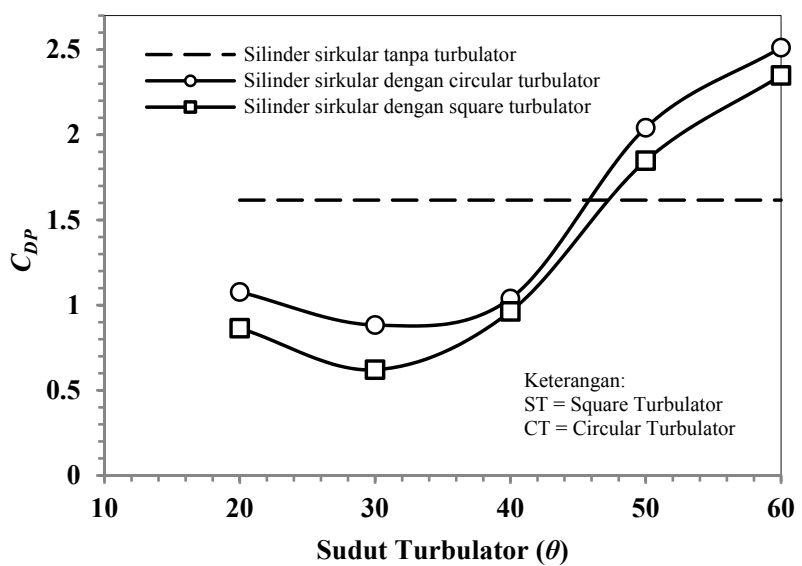

Gambar 6. Drag coefficient pressure

Untuk lebih jelasnya mengenai nilai koefisien drag pressure $\left(C_{D p}\right)$ masing-masing konfigurasi. Tabel 4 menunjukkan nilai $C_{D p}$ untuk silinder sirkular serta silinder sirkular dengan penambahan square dan circular turbulator. Pada tabel terlihat penggunaan dari square turbulator memiliki nilai $C_{D p}$ paling kecil. Penempatan square dan circular turbulator paling efektif diletakkan pada sudut $30^{\circ}$ dengan nilai $C_{D p}$ terendah. Ini membuktikan penggunaan turbulator efektif mengurangi nilai $C_{D p}$ pada silinder sirkular tunggal.

Tabel 4. Nilai $C_{D p}$ silinder sirkular dengan tambahan square turbulator (ST) dan circular turbulator (CT)

\begin{tabular}{|c|c|c|c|}
\hline \multirow[b]{2}{*}{$\begin{array}{l}\text { Posisi Sudut } \\
\text { Turbulator }\end{array}$} & \multicolumn{3}{|c|}{ Koefisien Drag Pressure $\left(C_{D_{p}}\right)$} \\
\hline & $\begin{array}{l}\text { Silinder } \\
\text { Sirkular }\end{array}$ & $\begin{array}{c}\text { Silinder } \\
\text { Sirkular }+ \\
\text { ST } \\
\end{array}$ & $\begin{array}{c}\text { Silinder } \\
\text { Sirkular }+ \\
\text { CT } \\
\end{array}$ \\
\hline & 1.62 & & 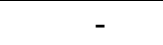 \\
\hline sudut $20^{\circ}$ & - & 0.86 & 1.08 \\
\hline sudut $30^{\circ}$ & - & 0.62 & 0.88 \\
\hline sudut $40^{\circ}$ & - & 0.96 & 1.04 \\
\hline sudut $50^{\circ}$ & - & 1.85 & 2.04 \\
\hline sudut $60^{\circ}$ & - & 2.35 & 2.51 \\
\hline
\end{tabular}

\section{KESIMPULAN}

Dari hasil penelitian dan pembahasan sebelumnya dapat disimpulkan sebagai berikut:

Penempatan square dan circular turbulator dengan sudut $\alpha=20^{\circ}, 30^{\circ}$ dan $40^{\circ}$ efektif mereduksi pressure drop dan $C_{D p}$. Reduksi pressure drop dan $C_{D p}$ tidak efektif lagi ketika turbulator dipasang pada sudut $\alpha=50^{\circ}$ dan $60^{\circ}$. Hal ini diakibatkan pada sudut $\alpha=20^{\circ}, 30^{\circ}$ dan $40^{\circ}$, shear layer yang terlepas dari square dan circular turbulator mampu mengakitasi boundary layer dari silinder sirkular tunggal. Sehingga mempercepat transisi boundary layer dari laminar ke turbulen pada silinder sirkular tunggal. Sedangkan pada sudut $\alpha=50^{\circ}$ dan $60^{\circ}$, shear layer yang dihasilkan turbulator terdefleksi kesisi luar silinder sirkular tunggal dan tidak mampu reattackment terhadap silinder sirkular tunggal. Hal ini mengakibatkan titik separasi dari silinder sirkular tunggal terjadi lebih awal dan wake yang dihasilkan oleh silinder sirkular tunggal lebih lebar. kondisi wake yang lebih lebar mengindikasikan gaya hambat juga besar pada silinder sirkular. Sehingga dengan meningkatnya gaya hambat pada silinder sirkular tunggal maka juga akan meningkatkan pressure drop pada saluran. Selain itu, dibandingkan dengan penggunaan circular turbulator, penggunaan square turbulator lebih efektif mereduksi nilai pressure drop dan nilai $C_{D p}$. Reduksi nilai pressure drop dan $C_{D p}$ terbaik pada silinder sirkular dengan penambahan square turbulator terjadi pada sudut $30^{\circ}$. Penggunaan dari square turbulator menghasilkan momentum aliran yang lebih besar dibandingkan penambahan cicular turbulator pada silinder sirkular tunggal.

\section{DAfTAR PUSTAKa}

[1] D. Yuvenda, "Karakterisasi Performa Mesin Sistem Dual Fuel Menggunakan Pressure Reducer Adaptive Dengan Variasi Konstanta ( K ) Pegas Helix Tekan Dan Tekanan," no. 2014, pp. 1-8, 2015.

[2] D. Yuvenda, B. Sudarmanta, and E. Alwi, "Analisis Kekuatan Pegas Pressure Reducer Sebagai Penurunan Tekanan Pada Mesin Duel Fuel," vol. 17, no. 2, 2017.

[3] P. J. Pritchard and J. C. Leylegian, Introduction to Fluid Mechanics, Eighth Edi. John Wiley \& Sons, INC, 2011.

[4] H. J. Niemann and N. Hölscher, "A review of recent experiments on the flow past circular cylinders," J. Wind Eng. Ind. Aerodyn., vol. 33, pp. 197-209, 1990.

[5] P. D. Weidman, "Wake Transition and Blockage Effects on Cylinder Base Pressures," California Institute of Technology, 1968.

[6] W. H. Bell, "Turbulence vs drag-some further considerations," Ocean Eng., vol. 10, pp. 47-63, 1983.

[7] P. W. Bearman and T. Morel, "Effect of free stream turbulence on the flow around bluff bodies," Prog. Aerosp. Sci., vol. 20, pp. 97-123, 1983.

[8] A. Daloglu, "Pressure drop in a channel with cylinders in tandem arrangement," Int. Commun. Heat Mass Transf., vol. 35, pp. 7683, 2008.

[9] M. M. Alam, H. Sakamoto, and M. Moriya, "Reduction of fluid forces acting on a single circular cylinder and two circular cylinders by using tripping rods," J. Fluids Struct., vol. 18, 
pp. 347-366, 2003.

[10] W. A. Widodo and R. P. Putra, "Reduction of drag force on a circular cylinder and pressure drop using a square cylinder as disturbance body in a narrow channel," Appl. Mech. Mater., vol. 493, pp. 192-197, 2014.

[11] Putra, Randi Purnama, Sutardi, and Wawan Aries Widodo. "The study on the effect of inlet disturbance body insertion on the flow pressure drop in a $90^{\circ}$ square elbow." In AIP Conference Proceedings, vol. 1983, no. 1, p. 020016. AIP Publishing, 2018.

[12] M. Ozgoren, "Flow structure in the downstream of square and circular cylinders," Flow Meas. Instrum., vol. 17, pp. 225-235, 2006.

\section{Biodata Penulis}

Randi Purnama Putra, lahir di Padang, 28 Juli 1988. Sarjana Pendidikan Teknik Otomotif dari Universitas Negeri Padang, lulus 2011. Tahun 2013 memperoleh gelar Magister Teknik Mesin Bidang Keahlian Rekayasa Konversi Energi pada Jurusan Teknik Mesin Institut Teknologi Sepuluh Nopember, Surabaya. Staf pengajar pada Jurusan Teknik Otomotif FT UNP sejak tahun 2013sekarang. Beberapa tema unggulan dalam penelitian penulis antara lain internal flow, aerodinamika kendaraan dan motor bakar dll.

Bahrul Amin, lahir di Palembang, 12 Februari 1963. Merupakan staf pengajar di jurusan Teknik
Otomotif FT UNP mulai dari tahun 1986 hingga Sekarang. Penulis menamatkan pendidikan level sarjana di prodi Pendidikan Teknik Otomotif UNP dan Prodi Teknik Mesin di STTP Padang. Jenjang Magister Pendidikan di prodi Pendidikan Teknologi Kejuruan Universitas Negeri Padang. Beberapa tema unggulan dalam penelitian penulis antara lain mekanika fluida, motor bensin, dan pendidikan teknologi kejuruan dll.

Dori Yuvenda, lahir di Bukittinggi, 1 November 1988. Merupakan staf pengajar di jurusan Teknik Otomotif FT UNP mulai dari tahun 2015 hingga Sekarang. Penulis menamatkan pendidikan level sarjana di prodi Pendidikan Teknik Otomotif FT UNP dan Jenjang Magister Teknik di prodi Teknik Mesin Bidang Keahlian Rekayasa Konversi Energi di Institut Teknologi Sepuluh Nopember. Beberapa tema unggulan dalam penelitian penulis antara lain motor bakar, mekanika fluida dll.

Nuzul Hidayat, lahir di Tigo Suku, 16 Januari 1987. Merupakan staf pengajar di jurusan Teknik Otomotif FT UNP mulai dari tahun 2013 hingga Sekarang. Penulis menamatkan pendidikan level sarjana di prodi Pendidikan Teknik Otomotif FT UNP dan Jenjang Magister Teknik di prodi Teknik Mesin Bidang Keahlian Rekayasa Konversi Energi di Institut Teknologi Sepuluh Nopember. Beberapa tema unggulan dalam penelitian penulis antara lain mekanika fluida, motor diesel dll. 